\title{
Corrigendum
}

Learning \& Memory 22: 494-498 (2015)

Corrigendum: The need for novel informatics tools for integrating and planning research in molecular and cellular cognition

Alcino J. Silva and Klaus-Robert Müller

On page 495, the third to last sentence of the Figure 1 caption reads "The second negative manipulation contributed $0.125 \times 0.51$ or 0.6025 ." This is an error and should read, "The second negative manipulation contributed $0.125 \times 0.5$ or $0.0625 . "$

On page 497, in the section headed "Research maps at work" the first sentence reads, "Figure 1 shows a research map for a molecular and cellular cognition article that includes 14 different causal experiments....." The number 14 is incorrect and should be 13 .

doi: $10.1101 / \operatorname{lm} .043869 .116$ 


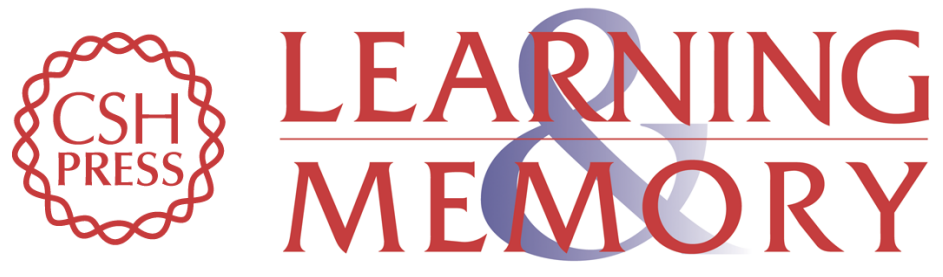

\section{Corrigendum: The need for novel informatics tools for integrating and planning research in molecular and cellular cognition}

Alcino J. Silva and Klaus-Robert Müller

Learn. Mem. 2016, 23:

Access the most recent version at doi:10.1101//m.043869.116

Related Content The need for novel informatics tools for integrating and planning research in molecular and cellular cognition

Alcino J. Silva and Klaus-Robert Müller

Learn. Mem. September , 2015 22: 494-498

License

Email Alerting Receive free email alerts when new articles cite this article - sign up in the box at the Service top right corner of the article or click here. 